\title{
MODERN METHODOLOGICAL APPROACHES TO THE INVESTIGATION OF ENSURING AND PROTECTION OF HUMAN RIGHT TO ACCESS TO PUBLIC INFORMATION
}

\author{
Oleksandr Sybiha', Tamara Hubanova ${ }^{2}$, Roman Melnyk ${ }^{3}$
}

\begin{abstract}
The purpose of the paper is to study the preconditions of the necessity to use new scientific tools during the study of issues related to the ensuring and protection of human right to access to public information; to characterize the main scientific approaches to modern researches in the sphere of safeguarding human right to access to public information; to identify promising directions for further research on this topic. Methodology. The paper presents the examples of a negative use of scientific methodology in conducting research in the area of administrative law and procedure and also draws attention to the need to reconsider an obsolete scientific methodology that does not correspond to the current realities and negatively affects the development of legal science. It indicates and characterizes the main preconditions of the necessity to use new scientific tools while investigating the issues related to ensuring and protection of human right to access to public information. In the context of the research of peculiarities of administrative and legal coverage and protection of human right to access to public information, it is proposed to use the systems approach, which is extremely effective in analysing complicated legal phenomena and processes and permits to study the peculiarities of substantive, procedure and procedural legal regulation as a cohesive whole. Practical implications. The system approach is an extremely promising technique for studying legal reality. Its use allows synthesizing all the knowledge about legal phenomena (legal rules, legal relations, legal consciousness, etc.), which is accumulated during the past stages of formation and development of domestic legal science, for a deeper insight into the development and functioning of law in general and administrative law in particular. Value/originality. Problems that exist in legal science in general and in the science of administrative law, in particular, can be solved only with the help of new scientific tools, specifically, by applying the system approach. The use of the systems approach in case of studying the issues of ensuring and protection of the human right to access to public information would allow combining all studies that were performed on this issue in substantive, procedure or procedural parts of the administrative law.
\end{abstract}

Key words: administrative law and procedure, methodology, public information, right to access to public information, administrative legal proceedings.

JEL Classification: I2, K1, K23

\section{Introduction}

The problems that currently exist in the science of administrative law and procedure are conditioned by different factors: rapid changes in the economic, political, and socio-cultural spheres of society, which require significant changes in the national legislation, the gap of branch studies to the needs of society, and therefore, the legal science doesn't manage to respond promptly and adequately to changes taking place in the society, etc. At the same time, the main problem of the modern legal science of Ukraine, and especially of the

\footnotetext{
Corresponding author:

${ }^{1}$ PJSC “International Academy of Personnel Management”, Ukraine.

E-mail: Sybiga@gmail.com

${ }^{2}$ PHEI “College of Finance and Law”, Ukraine.

E-mail: gubanovatamara@ukr.net

${ }^{3}$ Taras Shevchenko National University of Kyiv, Ukraine.

E-mail: r.melnik@ukr.net
}

science of administrative law and procedure, lies in the fact that scientific tools, which are used by the science in order to learn legal phenomena in the modern world, are out of date. It is impossible to produce high-tech products using obsolete equipment, as to improve the production and enhance its technological qualities, it is necessary to upgrade the equipment, which will produce such products, to elaborate administration at the enterprise, to advance professional competence of personnel, etc. The same processes should take place in the sphere of juridical science. The complication of 
social relations governed by law requires more advanced scientific tools, through which legal phenomena and processes are recognized in the modern world.

Unfortunately, we have to state that there is still no full comprehension of this problem among Ukrainian legal scholars, who automatically continue to explore the new phenomena for administrative law and procedure with the help of outdated methodology. Under the new conditions, the methodology that was used for the Soviet administrative law does more harm than provides benefits for the development of branch science, as its use often leads to wrongheaded or untrue results.

In the context of the outlined problem, it is relevant to define modern scientific tools of researches in the sphere of ensuring and protection of human right to access to public information. During the years of Ukraine's independence, firstly, there took place a gradual transformation of Ukrainian society with limited use of information into a new-day information society, and secondly, the rapid development of information relations in Ukraine, which was under the influence of a spread of the latest information technologies throughout the world, led to a gradual development of the national information legislation, thirdly, the mechanisms for enforcement of the right to access to public information were outlined in the current legislation by consolidating the relevant administrative procedures and access modes to information; fourthly, repeated violations of human right to access to public information by the public administration bodies favoured the consolidation of mechanism of judicial protection of the violated right in the current legislation. All these legal phenomena and processes can be investigated in the science of administrative law and procedure only with the help of new scientific instruments.

The general issues of methodology use in researches on the problems of administrative law and procedure were covered in the papers of V. B. Averianov, Ya. V. Zadorozhnia, V. K. Kolpakov, D. M. Lukianets, and many other domestic scholars.

At the same time, it should be noted that traditionally these issues are related to the theory of state and law, hence, are hesitantly raised by the representatives of administrative law and procedure, as a rule, in the context of covering the shortcomings of Soviet administrative law science or in conducting research, which is mainly based on the application of one approach of scientific knowledge.

\section{Problems of the application of scientific methodology in legal science}

The modern problem of using scientific methodology in juridical science has two dimensions. The first is that a formal attitude to the methodology became widespread in branch legal sciences, that is, it was given up to be used as a tool for research practice but it is used as an attribute for the execution of research work. If you get acquainted with the content of the research papers that were written in Ukraine over the last decade, you can see that very small percentage of them contain author's explanations regarding the methodology of research. In rare instances, the author explains a paper structure, specifies the framework of categories of the work, draws attention to the specifics of involved scientific tools in comparison with other works, which were written earlier on similar subjects, and suchlike. The majority of the authors mention the methods of scientific knowledge only when making up the introduction of a dissertation, which is a mandatory requirement for the defence of that sort of papers. This pro forma approach to the methodology usage doesn't have anything in common with a genuine research activity and its results. For example, hereupon, O. M. Mykolenko states that the lack of a methodological approach in the paper indicates an unsystematic character of information presentation (it becomes marked in the paper's structure or in the discrepancy between the subsection title and its actual content), the lack of a scientific problem that is solved in the course of study (so this kind of paper is usually descriptive), the lack of conclusions that would solve the existing problem (therefore, such a paper is overloaded with conclusions, which only state the fact that exists in a real legal reality) (Mykolenko, 2018).

The second dimension of the current problem of scientific methodology application in legal science is that fresh problems of the science of administrative law and procedure require new tools for their solution.

\section{Preconditions of the need to use new scientific tools for research of ensuring and protection of human right to access to public information}

Among the conditions for the need to use new scientific tools in modern researches of administrative and legal phenomena in general and issues of ensuring and protecting the human right to access to information, in particular, one can distinguish the following.

1. The transformation of Ukrainian society into an information society. For example, O. V. Lohinov outlines three types of information society:

1) a society of new type, which is evolved as a result of the global social revolution and generated by the rapid development and convergence of information and communication technologies;

2) a society of knowledge, that is, a society where the main condition of the welfare of every person and every state is knowledge gained through unimpeded access to information and the ability to deal with it;

3) a global society where the information exchange will have neither temporal, nor spatial or political limits that, on the one hand, will promote the interpenetration of cultures, and on the other hand, will open up new 
opportunities for self-identification to each community (Lohinov, 2005).

The development of the national information legislation and promotion of research activities in this sphere is conditioned, first of all, by the fact that Ukrainian society being an information society of new kind tries to transform into an information society, which refers to the second or third type, which not only declares information rights of natural and legal persons but also creates real conditions for their implementation and provides legal mechanisms for protection of violated rights.

2. Reform of administrative law as a branch of law. This reform concerns the institutional issues of administrative law because it involves reconsidering and clarifying the content of the subject and the method of administrative-legal regulation, the system of administrative law, the system of subjects of administrative law and their legal status, etc. These changes influence the framework of categories and concepts of administrative law. The terms as "public administration", "administrative procedure", "administrative services" were rarely used in scientific works at the end of XIX - beginning of $\mathrm{XX}$ centuries and have recently become the key categories of modern administrative law. For example, when it investigates the peculiarities of ensuring and protection of human right to access to public information, it raises the question of the distinction between the subject of administrative law and the subject of information law. On the one hand, there is the re-examination of administrative law system with the clarification of elements included in this system but, on the other hand, there is an endeavour to substantiate the expediency of establishment of an independent branch in Ukrainian law system - information law.

The right to information and the right to access to public information, as a rule, are implemented through administrative procedures provided for by the current legislation and are related to the provision of administrative services. In this case, there is a need to specify the place of the procedure for access to public information in the general system of administrative procedures, to determine the place of the subjects of relations in the sphere of access to public information in the general system of subjects of administrative law, as well as to define the peculiarities of the provision of public information in the general system of administrative services.

The issues under consideration can't be solved using outdated scientific tools. They require the search for new scientific approaches to highlight the problems of administrative law enforcement and protection of human right to access to public information.

3. The lack of comprehensive researches that would, firstly, combine all early studies on ensuring and protection of human right to access to public information and, secondly, unite the analysis of substantive, procedure and procedural administrative law on ensuring and protection of the human right to access to public information.

\section{Comprehensive analysis of researches on ensuring and protection of human right to access to public information}

The right to information, especially its enforceability and implementation, is a research subject of constitutional, administrative, and information law. Therefore, in this area, it is important to use not only the achievements of administrative law and procedure but also the achievements of other branch legal sciences. The holistic character of a research lies in the fact that a scholar not only investigates a legal phenomenon with the help of existing tools but also takes into account the results of previous investigations, compares them with the conclusions that the author achieved in the course of the study, tries to identify tendencies which were conditioned by a certain historical stage, etc.

For example, the analysis of scientific papers on ensuring and protection of human right to access to public information shows as follows:

- the studies of representatives of constitutional law were mainly focused on the reasons for non-compliance with the constitutional requirements for ensuring access to public information by public administration bodies, the issue of essence of human right to access to public information and mechanism of its implementation were fragmentarily considered in the following papers (N. V. Kushkova, O. V. Nesterenko, E. P. Teptiuk, and others);

- the papers of representatives of administrative and information laws considered the issues of ensuring human right to public information, as they comprehensively studied the content of such concepts as "public information", "human right to access to public information", "procedure of public information access" and others (V. Yu. Baskakov, T. V. Hrushkevych, Yu. V. Dyka, L. V. Kuzenko, O. O. Kukshynova, K. S. Mashtak, S. M. Taradai, and others).

It is very important that the study on the issues of ensuring and protection of human right to access to public information combines an analysis of the rules of substantive, procedure and procedural administrative law. Today, it is relevant in the context of reforming administrative law and formation of its system. The emergence of administrative legal proceedings in Ukraine contributed to the development of democratisation of our society but also generated a number of theoretical problems in the doctrine of administrative law, some of which are currently unresolved:

a) is the set of rules regulating administrative legal proceedings a part of the system of administrative law (its branch or sub-branch) or does it create an independent branch of law - "administrative procedural law"? 
b) if administrative legal proceedings are regulated by administrative procedural rules, so which rules do regulate the activities of public administration bodies regarding the provision of services (by administrative procedure or administrative procedural rules)?

c) the recognition of the existence of administrative procedural rules along with administrative procedure rules does not comport with contemporary views of the types of legal rules in the theory of law that currently divides the legal rules into two types - substantive and procedural.

Thereareconstantdiscussionsamongtherepresentatives of administrative law towards the abovementioned issues that are presented in juridical literature (V. M. Bevzenko, A. T. Komziuk, O. V. Kuzmenko, and others). At the same time, it is obvious that there is a range of issues that require a comprehensive analysis in the area of administrative law and procedure, that is, taking into account the peculiarities of substantive, procedure and procedural parts of the administrative law. For example, the investigation of human right to access to public information can be performed solely from the point of view of administrative substantive law and such study should focus on: a) the concept of information and its types; b) the concept of public information and its types; c) the content of human right to access to public information in the system of other administrative rights of a person; d) the characteristic nature of administrative and legal status of a person who has the right to access to public information, etc.

The human right to access to public information can be investigated exclusively from the point of view of administrative procedure law. In such studies, attention will be drawn to: a) the mechanisms, methods, types of enforcement of the right to access to public information; $b$ ) stages or steps of the procedure for the implementation of this constitutional right; c) the legal status of participants of the enforcement of the right to access public information, etc.

But theinvestigation, for example, ofjudicial protection of human right to access to public information, cannot be performed solely from the point of administrative procedural law, because the disclosure of this topic is not limited by the solution to procedural issues, it is closely related to the peculiarities of regulation of the right to access to public information by substantive and procedural rules of administrative law.

The analysis of scientific papers shows that the substantive and procedural rules of administrative law, which establish the content of the human right to access to public information and regulate the procedure for the implementation of this right, are researched to the full extent in the science of administrative law of Ukraine. While the administrative procedural rules regulating the procedure of consideration of disputes by administrative courts over appeals against decisions, actions or passivity of public information administrator in terms of access to public information, are not adequately investigated.
Recently, studies connected with the peculiarities of administrative legal proceedings in certain cases categories have been enhanced in Ukraine (O. V. Bacherikov, T. F. Veselska, Ya. S. Riabchenko, N. V. Shevtsova, O. V. Yatsun etc.). It should be noted that most of them mainly focus on the problems of administrative process avoiding the examination of issues of substantive and procedure parts of the administrative law. For example, Ya. S. Riabchenko in her work, devoted to the peculiarities of administrative legal proceedings on issues of appealing regulatory documents, covered the specification of the content of the procedure for appealing regulatory acts in administrative legal proceedings and the definition of the principles of this proceeding (Riabchenko, 2010). O. V. Yatsun describing the peculiarities of administrative proceedings in land disputes confined herself, firstly, to the description of the content, features, and types of land disputes, which are settled in the procedure of administrative legal proceedings, and secondly, the definition of the procedural principles of proceedings for the consideration and resolution of land disputes with the participation of entities of public administration (Iatsun, 2011).

At the same time, the science of administrative law and procedure has achievements, which comprehensively consider the problems of administration of justice in administrative courts. For example, O. V. Yevsikova investigating the peculiarities of protection of tax relations in administrative courts of Ukraine lays emphasis on the characteristics of content of tax relations in Ukraine and the peculiarities of their legal regulation, and then continues with the analysis of the procedural arrangement for the consideration of cases in a county court, within the framework of the appellate and cassation proceedings (Ievsikova, 2012). A similar approach was used in the paper of A. V. Krasovska. Considering the peculiarities of administrative legal proceedings in cases over the termination of legal entities' activities on claims of authorities, in the first chapter of the work, the scholar focuses on the consideration of the substantive grounds of the claim's causes for the termination of legal entities' activities and in the second and third chapters reveals the specifics of administrative proceedings in this category of cases (Krasovska, 2012).

The need for a comprehensive study of the issues of judicial protection of human right to access to public information is also confirmed by the existence of the Resolution of the Plenum of the High Administrative Court of Ukraine dated September 29, 2016, No. 10 "On Practical Application of the Law on Access to Public Information by Administrative Courts" (High Administrative Court of Ukraine, 2016). The content of this resolution shows that the main problem of considering disputes over appeals against decisions, actions or inactivity of an information administrator 
by administrative courts, in terms of access to public information, doesn't lie in the weaknesses of administrative procedural legislation or shortcomings in the activity of administrative courts, but in the peculiarities of administrative and legal regulation of substantive and procedural relations, that is, related to the definition of content and types of public information, information access modes, procedures for access to public information, including classified information, and so on.

\section{New scientific tools in solving problems in the administrative law}

In our opinion, the foregoing is a sufficient reason to argue that currently existing problems in juridical science in general and in the science of administrative law, in particular, can be solved only with the help of new scientific tools. The conceptual framework, which successfully has been used by the science for many years, malfunctions in increasing frequency, in particular, because of its inconsistency to contemporary tasks and their very formulation. The systems approach acts as one of the ways of such deepening, associated with the development of new methodological directions in science (Melnyk, 2010).

The systems approach is extremely effective in the analysis of complex objects, which include the sphere of providing and protection of the human right to access to public information. This sphere has several qualitative definitions (substantive, procedural, procedure) and, in this respect, several directions of its development (clarification of the content of the right to access public information, improvement of the procedure for access to public information, generalization of administrative courts' jurisdiction in order to increase the level of protection of human right in the sphere of access to public information).

To sum up, we want to emphasize that the systems approach is an extremely promising method for studying legal reality. Its application permits to synthesize all the knowledge about legal phenomena (legal rules, legal relations, legal consciousness, etc.), which was accumulated during the past stages of the formation and development of domestic legal science, for a deeper insight into the laws of development and functioning of law in general and administrative law in particular (Melnyk, 2010).

\section{Conclusions}

In the light of the analysis of modern methodological approaches to research on the provision and protection of human right to access to public information, the following conclusions can be drawn.

1. The current problem of using scientific methodology in legal science has two dimensions. The first is that in branch legal sciences, there is a widespread conventional attitude to the methodology, that is, it was given up to be used as a tool for research performance but is used as an attribute for the execution of research work. The second is that fresh problems of the science of administrative law and the procedure require a new scientific tool for their solution.

2. Among the preconditions for the need to use new scientific tools in modern studies of administrative and legal coverage and protection of human right to access to public information, it is necessary to highlight the following: a) the transformation of Ukrainian society into an information and its subsequent development in a new direction; b) the reform of administrative law as a branch of law with the gradual definition of legal rules' place in the system of Ukrainian law that regulate administrative proceedings; c) the lack of comprehensive research that would, first of all, combine all previous research on the issues of ensuring and protection of human right to access to public information and, secondly, unite the analysis of the rules of substantive, procedure, and procedural administrative law on ensuring and protection of human right to access to public information.

3. The current problems of juridical science in general and the science of administrative law, in particular, can be solved only with the help of new scientific tools, namely, by applying the systems approach. The application of systems approach in the study of issues of ensuring and protection of the human right to access to public information will give an opportunity to combine all studies that have taken place on this issue in substantive, procedure or procedural parts of the administrative law.

4. Based on the foregoing, we believe that the issue of research methodology improvement in the sphere of ensuring and protection of human right to access to public information is a promising one for the further development of administrative law and procedure.

\section{References:}

Mykolenko, O. M. (2018). Funktsii administratyvno-deliktnoho prava : teoriia i praktyka: monohrafiia [Functions of administrative-tort law: theory and practice: monograph]. Odesa: Feniks (in Ukrainian)

Loginov, O. V. (2005) Administratyvno-pravove zabezpechennia informatsiinoi bezpeky orhaniv vykonavchoi vlady [Administrative and legal support of information security of executive authorities] (PhD Thesis), Kyiv: National Academy of Internal Affairs.

Riabchenko, Ya. S. (2010). Oskarzhennia normatyvno-pravovykh aktiv v administratyvnomu sudochynstvi [Appeal of regulatory acts in administrative proceeding] (PhD Thesis), Kharkiv: Yaroslav Mudryi National Law University. 
Iatsun, O. V. (2011). Osoblyvosti provadzhennia po zemelnym sporam za uchastiu subiektiv publichnoi administratsii v poriadku administratyvnoho sudochynstva [Peculiarities of proceedings on land disputes with the participation of public administration actors in the procedure of administrative legal proceedings] (PhD Thesis), Zaporizhzhia: Zaporizhzhia National University.

Ievsikova, O. V. (2012). Zakhyst podatkovykh pravovidnosyn u administratyvnykh sudakh Ukrainy [Protection of tax relations in administrative courts of Ukraine] (PhD Thesis), Kyiv: National Aviation University.

Krasovska, A. V. (2012). Osoblyvosti administratyvnoho sudochynstva u spravakh pro prypynennia yurydychnykh osib za pozovamy subiektiv vladnykh povnovazhen [Peculiarities of administrative proceedings in cases over termination of legal entities' activities on claims of authorities] (PhD Thesis), Lviv: Lviv University of Business and Law.

High Administrative Court of Ukraine (2016). Pro praktyku zastosuvannia administratyvnymy sudamy zakonodavstva pro dostup do publichnoi informatsii : Postanova Plenumu Vyshchoho administratyvnoho sudu Ukrainy [On Practical Application of the Law on Access to Public Information by Administrative Courts: the Resolution of the Plenum of the High Administrative Court of Ukraine dated 29.09.2016, No. 10]. Retrieved from: http://www.vasu.gov.ua/plenum/post_plenum/postanova_plenumu_10_29-09-2016/

Melnyk, R. S. (2010). Systema administratyvnoho prava Ukrainy [The system of administrative law in Ukraine] (PhD Thesis), Kharkiv: Kharkiv National University of Internal Affairs. 